\title{
Synthesis and Analysis of Antimicrobial Properties of Isoxazoline
}

\author{
Manorama B. Motegaonkar* \\ Department of Chemistry, \\ Azad College, Ausa. Dist. Latur (M.S.) India.
}

\begin{abstract}
I Abstract:- A simple procedure for the synthesis of isoxazole derivatives was developed. Cyclocondensation reaction of chalcones with hydroxylamine hydrochloride catalyzed by an acid produced isoxazoles. Chalcones were synthesized by the condensation product of acetophenone in combination with aromatic aldehydes in presence of strong base. The chalcone synthesized by base catalyzed condensation of 3-acetyl-6methyl-2H- pyran-2,4-(3H) dione (DHA) with different aromatic aldehyde in good yields. These chalcones were used for synthesis of derivatives i.e. isoxazoline. The synthesized new compounds were characterized by spectral studies i.e. IR, ${ }^{1}$ HNMR and mass spectral analysis and elemental analysis; before being were screened in vitro for their antimicrobial susceptibilities against different bacteria and fungi species. The derivatives were further used for the estimation of its biological properties. From the study it was found that the synthesized compounds are efficient for further researchwork.
\end{abstract}

II Keywords: Dehydroacetic acid (DHA), Chalcone, 3cinnamoyl-4-hydroxy-6-methyl-2- pyrones, IR, ${ }^{1}$ HNMR, Antibacterial activity, Antifungal activity, Isoxazoline.

\section{INTRODUCTION}

Isoxazoline is a five member heterocyclic compounds containing $\mathrm{N}$ and $\mathrm{O}$ atoms adjacent to each other's. The dihydricderivative of isoxazoline are also called as isoxazole the compound containing $\mathrm{N}$ functionality $(-\mathrm{C}=\mathrm{N}-\mathrm{O}-)$ undergo cyclo addition reaction with an $\alpha, \beta$-unsaturated carbonyl compound or with an alkane to produce isoxazoline having an -N-O- moiety, $\mathrm{O}$ being next to $\mathrm{N}$ rises the barrier to $\mathrm{N}$ inversion to such extent that a temperature lower than the ambient, individual can be identified by ${ }^{1} \mathrm{H}$ NMR spectroscopy ${ }^{1-2}$.

Synthesis of isoxazoline derivatives has been a subject of consistent interest because of the wide applications of such heterocyclic in pharmaceutical as well as agrochemical industry ${ }^{3}$. Numerous compounds containing isoxazole, pyrazole and pyrimidine moiety have been reported as active hypoglycemic, antidiabetic, antipyretics, analgesics, antiinflammatory, antiviral, antiallergic, anticancer agent, antidrepressant and antimicrobial agents which include antibacterial sulfonamides, semisynthetic penicillins and cephalosporines $^{4-6}$. These discoveries led the scientist to attempt the synthesis of isoxazole, pyrazole and pyrimidine derivatives from the chalcones made from aromatic aldehydes and aromatic ketones and to evaluate the synthesized compounds against antimicrobial, antifungal and antitubercular activity ${ }^{7-10}$.

The reactive intermediate chalcones involved in their synthesis also exhibit wide range of biological activities ${ }^{11}$. These properties were used in the research to find some novel compounds for pharmaceutical and agricultural industry.

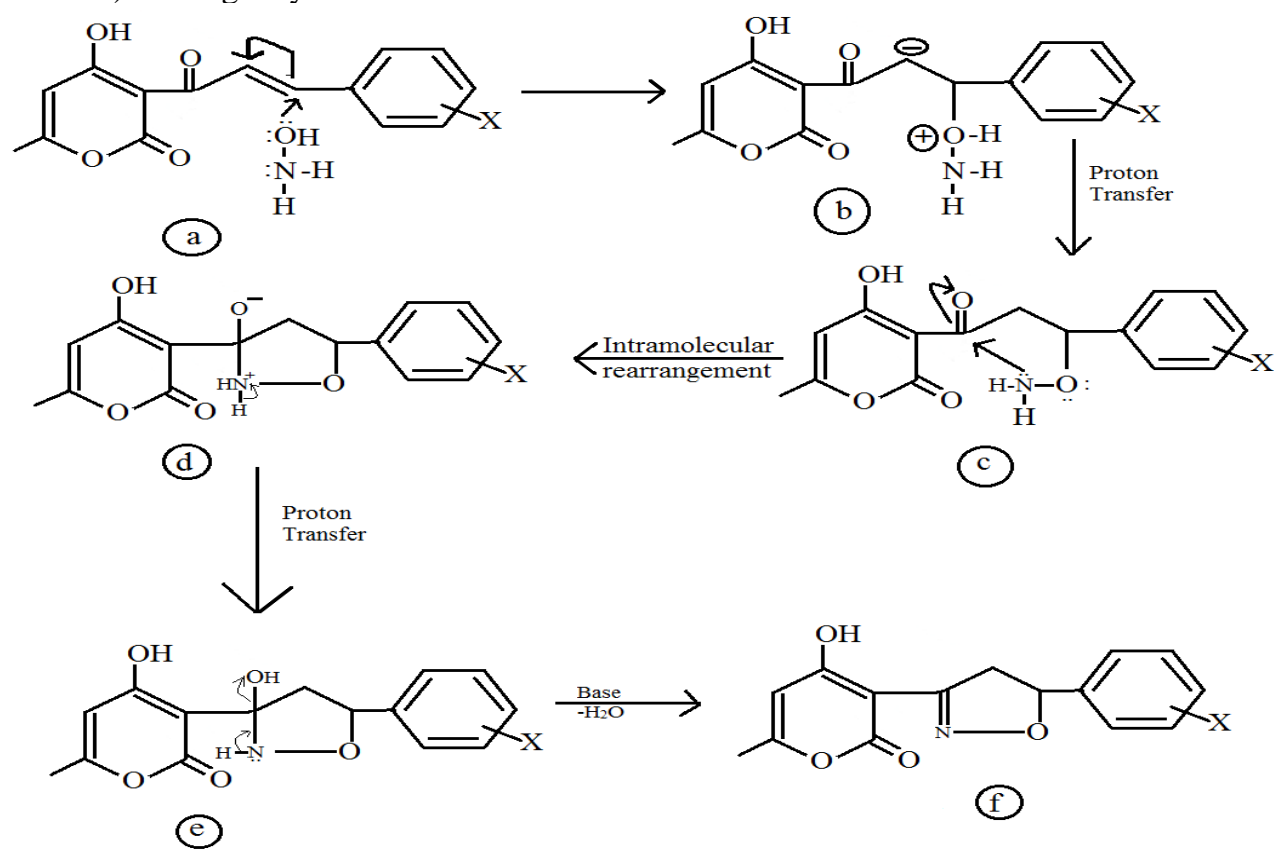

Fig. 1 Mechanism of isoxazoline synthesis 


\section{METHODOLOGY}

\section{Synthesis of Substituted isoxazoline}

A mixture of DHA chalcone $(0.001 \mathrm{~mol})$ and hydroxyl amine hydrochloride $(0.0015 \mathrm{~mol})$ and sodium acetate $(0.002 \mathrm{~mol})$ were refluxed for $6-7 \mathrm{hr}$ in $15 \mathrm{ml}$ ethanol. After completion of the reaction (checked by TLC). The reaction mixture was cooled and poured on ice cold water. The separated solid product was filtered and further washed with cold water, dried and further recrystallized from ethyl alcohol. The structures of isoxazolines were confirmed by spectral analysis (IR, ${ }^{1} \mathrm{H}$ NMR, Mass and Elemental analysis) ${ }^{12-13}$.

\section{Analytical Characterizations}

The IR spectra of compound were recorded on FT-IR spectrometer, ${ }^{1} \mathrm{H}$ NMR AVANCE $500 \mathrm{MHz}$ $\left(\mathrm{CDCl}_{3}\right)$ instrument using TMS as an internal standard (chemical shift are given in $\delta \mathrm{ppm}$ ). The mass spectra recorded on SHIMADZU spectrometer.

\section{IR Spectra}

The IR spectra showed characteristics absorption band at $1610-1640 \mathrm{~cm}^{-1}$ due to the $\mathrm{C}=\mathrm{N}$ stretching. A broad peak showed in between $3000-3500 \mathrm{~cm}^{-1}$ is due to the hydroxyl group in synthesized compounds.

\section{${ }^{1} \mathrm{H}$ NMR spectra}

${ }^{1} \mathrm{H}$ NMR of isoxazoline showed following type of peak which confirms the formation of product $\delta$ 3.0-3.8 (dd, $2 \mathrm{H}, \mathrm{CH}_{2}$ ) i.e. $\mathrm{H}_{\mathrm{A}}$ and $\mathrm{H}_{\mathrm{B}}$ of isoxazoline ring. $\delta$ 5.0-5.4 $(\mathrm{t}, 1 \mathrm{H}, \mathrm{CH})$ i.e. $\mathrm{Hx}$ of isoxazoline ring. $\delta 14.2-16.0(\mathrm{~s}, 1 \mathrm{H}$, $\mathrm{OH})$ while the ring peak at $\delta 2.15-2.8\left(\mathrm{~s}, 3 \mathrm{H}, \mathrm{Ar}-\mathrm{CH}_{3}\right)$ all such peaks are observed.

\section{Mass Spectra}

Mass Spectra of representative compounds confirmed the molecular formula weight of respective compounds.

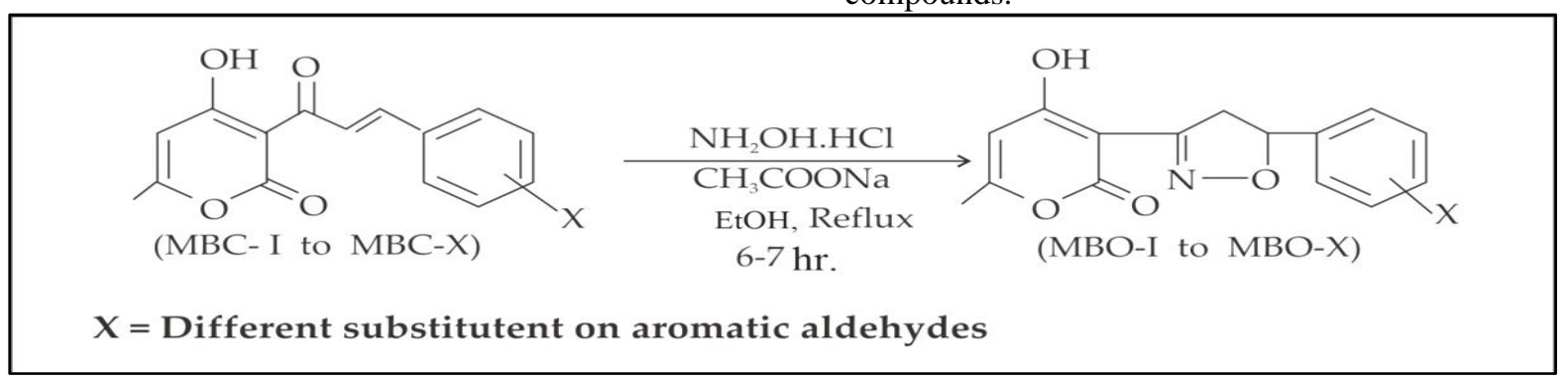

Fig. 2 Synthesis of 3-(4-hydroxy-6-methyl-2-oxa-2H-pyran-3yl)-5-(Substituted aryl)-4,5-dihydro-2-isoxazoline (MBO-I- MBO-V)

\section{Synthesis of 3-(4-hydroxy-6-methyl-2-oxa-2H-pyran-3yl)-5-(2-florophenyl)-4,5-dihydro-2-isoxazoline (MBO-I-V)}

A mixture of 1-(4-hydroxy-6-methyl-2-oxa-2H-pyran-3yl)-3-(2-florophenyl)-2-Propenone (0.001mol) hydroxylaminehydrochloride $(0.0015 \mathrm{~mol})$ and sodium acetate $(0.002 \mathrm{~mol})$ in $15 \mathrm{ml}$ ethanol was refluxed for 6-7 hr. After completion of the reaction checked by TLC, the reaction mixture was cooled and poured on ice cold water. The separated solid product was filtered, washed with cold water, dried and recrystallized from ethanol to give the corresponding product 3-(4hydroxy-6-methyl-2-oxa-2H-pyran-3yl)-5-(2-florophenyl)-4,5-dihydro-2-isoxazoline.

Similarly all the other compounds of the series also prepared by the same procedure. The yield and M. P. are listed in Table 1.

Table 1 Physical data of 3-(4-hydroxyl-6-methyl-2-oxa-2H-Pyran-3-yl) 5-

(Substituted aryl) -4,5-dihydro-2-isoxazoline (MBO-I-MBO-V)

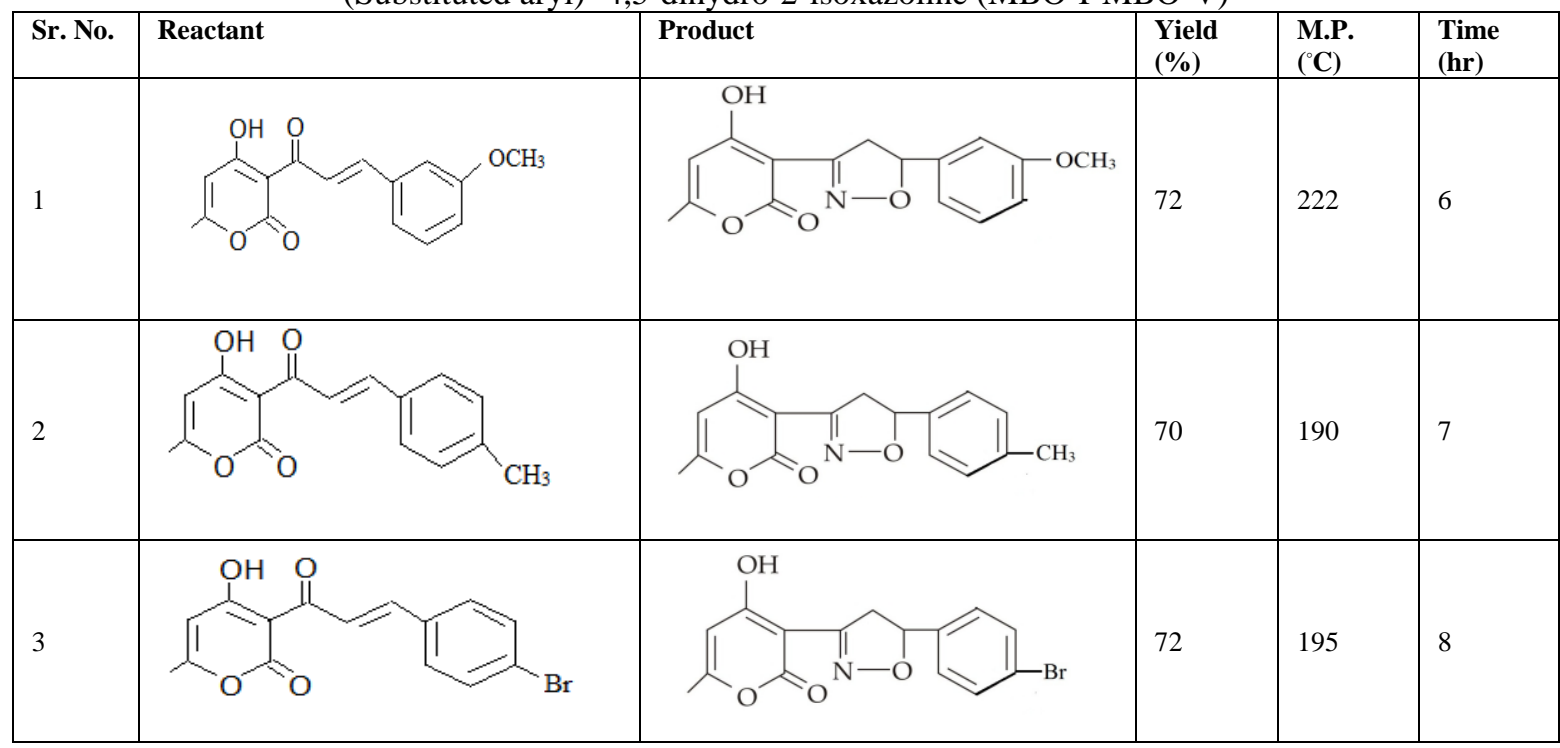




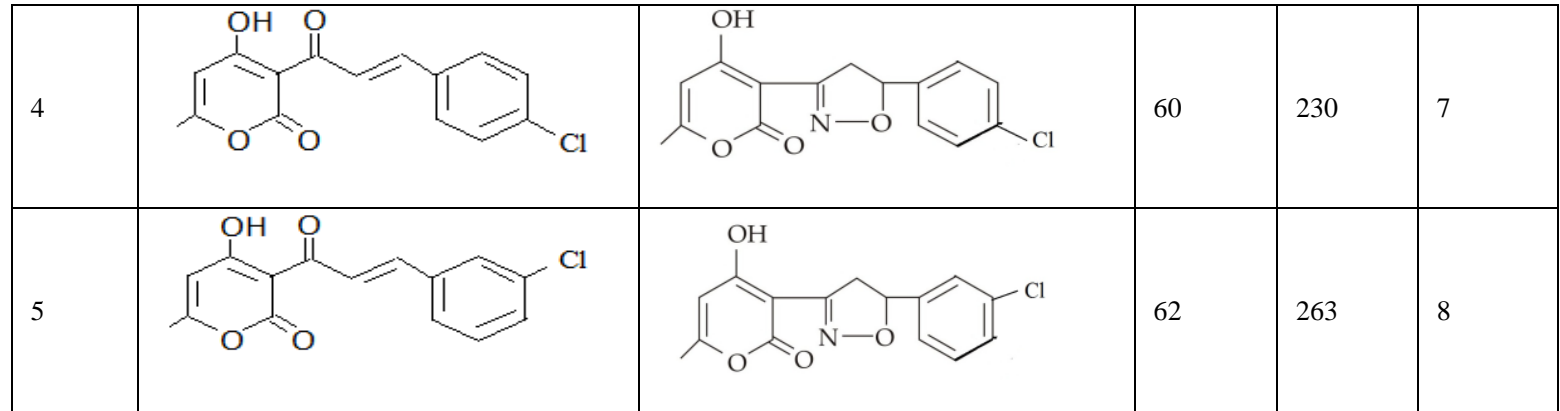

\section{Spectroscopic data}

\section{Compound No. MBO-I}

3-(4-hydroxy-6-methyl-2.oxa-2H-pyran-3-yl)-5-(3methoxyphenyl)-4,5-dihydro-

\section{2- Isoxazoline}

IR(KBr, $\left.\mathbf{c m}^{-1}\right)$ : 3422 (OH str.), 2970 (C-H str. of $\left.\mathrm{CH}_{3}\right)$, $1720(\mathrm{C}=\mathrm{O}$ lactone $), 1622(\mathrm{C}=\mathrm{N}$ str. of Isoxazoline ring), 1230 (C-N str. of Isoxazoline ring), 822 (N-O Str.)

${ }^{1} \boldsymbol{H} \boldsymbol{N M R}\left(\boldsymbol{C D C l} \boldsymbol{C l}_{3}, \boldsymbol{\delta} / \boldsymbol{p p m}\right): \delta 2.1\left(3 \mathrm{H}, \mathrm{s}, \mathrm{CH}_{3}\right), \delta 3.4\left(1 \mathrm{H}_{\mathrm{A}}, \mathrm{dd}\right.$, $\mathrm{CH}_{2}$ Isoxazoline ring), $\delta 3.9\left(1 \mathrm{H}_{\mathrm{B}}, \mathrm{dd}, \mathrm{CH}_{2}\right.$ Isoxazoline ring $), \quad \delta 5.4\left(1 \mathrm{H}_{\mathrm{X}}, \mathrm{t}, \mathrm{CH}\right.$ Isoxazoline ring $), \delta 6.0\left(1 \mathrm{H}, \mathrm{s}, \mathrm{C}^{5}\right.$ DHA), $\delta 6.2-8.0(4 \mathrm{H}, \mathrm{m}, \mathrm{Ar}-\mathrm{H}), \delta 15.2(1 \mathrm{H}, \mathrm{s}, \mathrm{OH})$

$\operatorname{Mass}(\mathrm{m} / \mathrm{z}):(\mathrm{M}+1) 300$

\section{Compound No. MBO-II}

3-(4-hydroxy-6-methyl-2.oxa-2H-pyran-3-yl)-5-(4methylphenyl)-4,5-dihydro-2- Isoxazoline

IR(KBr, $\left.\mathbf{c m}^{-1}\right): 3280$ (OH str.), $2932\left(\mathrm{C}-\mathrm{H}\right.$ str. of $\left.\mathrm{CH}_{3}\right)$, $1720(\mathrm{C}=\mathrm{O}$ lactone), $1615(\mathrm{C}=\mathrm{N}$ str. of Isoxazoline ring), 1280 (C-N str. of Isoxazoline ring), 845 (N-O Str.)

${ }^{1} \boldsymbol{H} \boldsymbol{N M R}\left(\boldsymbol{C D C l}_{3}, \boldsymbol{\delta} / \boldsymbol{p p m}\right): \delta 2.4\left(6 \mathrm{H}, \mathrm{s}, 2 \mathrm{XCH}_{3}\right), \delta 3.0\left(1 \mathrm{H}_{\mathrm{A}}\right.$, dd, $\mathrm{CH}_{2}$ Isoxazoline ring $), \delta 3.6\left(1 \mathrm{H}_{\mathrm{B}}, \mathrm{dd}, \mathrm{CH}_{2}\right.$ Isoxazoline ring $), \quad \delta 5.2\left(1 \mathrm{H}_{\mathrm{X}}, \mathrm{t}, \mathrm{CH}\right.$ Isoxazoline ring $), \delta 6.0\left(1 \mathrm{H}, \mathrm{s}, \mathrm{C}^{5}\right.$ DHA), $\delta 6.8-8.4(4 \mathrm{H}, \mathrm{m}, \mathrm{Ar}-\mathrm{H}), \delta 14.8(1 \mathrm{H}, \mathrm{s}, \mathrm{OH})$

$\operatorname{Mass}(m / z):(\mathrm{M}+1) 286$

\section{Compound No. MBO-III}

3-(4-hydroxy-6-methyl-2.oxa-2H-pyran-3-yl)-5-(4-

Bromophenyl)-4,5-dihydro-

2- Isoxazoline

IR(KBr, $\left.\boldsymbol{c m}^{-1}\right): 3400$ (OH str.), $2925\left(\mathrm{C}-\mathrm{H}\right.$ str. of $\left.\mathrm{CH}_{3}\right)$, 1725 ( $\mathrm{C}=\mathrm{O}$ lactone), $1622(\mathrm{C}=\mathrm{N}$ str. of Isoxazoline ring), 1265 (C-N str. of Isoxazoline ring), 852 (N-O Str.)

${ }^{1} \boldsymbol{H} \boldsymbol{N M R}\left(\boldsymbol{C D C l} \boldsymbol{C l}_{3}, \boldsymbol{\delta} / \boldsymbol{p p m}\right): \delta 2.2\left(3 \mathrm{H}, \mathrm{s}, \mathrm{CH}_{3}\right), \delta 3.6\left(1 \mathrm{H}_{\mathrm{A}}, \mathrm{dd}\right.$, $\mathrm{CH}_{2}$ Isoxazoline ring), $\delta 4.0\left(1 \mathrm{H}_{\mathrm{B}}, \mathrm{dd}, \mathrm{CH}_{2}\right.$ Isoxazoline ring $), \delta 4.8\left(1 \mathrm{H}_{\mathrm{X}}, \mathrm{t}, \mathrm{CH}\right.$ Isoxazoline ring $), \delta 5.9\left(1 \mathrm{H}, \mathrm{s}, \mathrm{C}^{5}\right.$ DHA $), \delta 6.0-8.0(4 \mathrm{H}, \mathrm{m}, \mathrm{Ar}-\mathrm{H}), \delta 16.0(1 \mathrm{H}, \mathrm{s}, \mathrm{OH})$

$\operatorname{Mass}(\boldsymbol{m} / \mathbf{z}):(\mathrm{M}+) 350,(\mathrm{M}+2) 352$

Compound No. MBO-IV

3-(4-hydroxy-6-methyl-2.oxa-2H-pyran-3-yl)-5-(4-

Chlorophenyl)-4,5-dihydro-

2- Isoxazoline
IR(KBr, $\left.\boldsymbol{c m}^{-1}\right): 3300$ (OH str.), 2970 (C-H str. of $\left.\mathrm{CH}_{3}\right)$, $1720(\mathrm{C}=\mathrm{O}$ lactone $), 1630(\mathrm{C}=\mathrm{N}$ str. of Isoxazoline ring $)$, 1232 (C-N str. of Isoxazoline ring),

${ }^{1} \boldsymbol{H} \boldsymbol{N M R}\left(\boldsymbol{C D C l} \mathbf{C l}_{3}, \boldsymbol{\delta} / \mathbf{p p m}\right): \delta 2.4\left(3 \mathrm{H}, \mathrm{s}, \mathrm{CH}_{3}\right), \delta 3.8\left(1 \mathrm{H}_{\mathrm{A}}, \mathrm{dd}\right.$, $\mathrm{CH}_{2}$ Isoxazoline ring $), \quad \delta 4.2\left(1 \mathrm{H}_{\mathrm{B}}, \mathrm{dd}, \mathrm{CH}_{2}\right.$ Isoxazoline ring $), \delta 5.8\left(1 \mathrm{H}_{\mathrm{X}}, \mathrm{t}, \mathrm{CH}\right.$ Isoxazoline ring $), \delta 6.0\left(1 \mathrm{H}, \mathrm{s}, \mathrm{C}^{5}\right.$ DHA), $\delta 6.2-8.2(4 \mathrm{H}, \mathrm{m}, \mathrm{Ar}-\mathrm{H}), \delta 15.8(1 \mathrm{H}, \mathrm{s}, \mathrm{OH})$

Mass $(\mathbf{m} / \mathbf{z}):(\mathrm{M}+) 305(\mathrm{M}+1) 307$

Compound No. MBO-V

3-(4-hydroxy-6-methyl-2.oxa-2H-pyran-3-yl)-5-(3Chlorophenyl)-4,5-dihydro-

2- Isoxazoline

IR(KBr, $\left.\mathbf{c m}^{-1}\right)$ : 3320 (OH str.), 2979 (C-H str. of $\left.\mathrm{CH}_{3}\right)$, $1722(\mathrm{C}=\mathrm{O}$ lactone $), 1632(\mathrm{C}=\mathrm{N}$ str. of Isoxazoline ring), 1230 (C-N str. of Isoxazoline ring)

${ }^{1} \boldsymbol{H} \boldsymbol{N M R}\left(\boldsymbol{C D C l} \boldsymbol{l}_{3}, \boldsymbol{\delta} / \boldsymbol{p p m}\right): \delta 2.2\left(3 \mathrm{H}, \mathrm{s}, \mathrm{CH}_{3}\right), \delta 4.0\left(1 \mathrm{H}_{\mathrm{A}}, \mathrm{dd}\right.$, $\mathrm{CH}_{2}$ Isoxazoline ring $), \quad \delta 4.6\left(1 \mathrm{H}_{\mathrm{B}}, \mathrm{dd}, \mathrm{CH}_{2}\right.$ Isoxazoline ring $), \quad \delta 5.6\left(1 \mathrm{H}_{\mathrm{X}}, \mathrm{t}, \mathrm{CH}\right.$ Isoxazoline ring $), \quad \delta 6.0\left(1 \mathrm{H}, \mathrm{s}, \mathrm{C}^{5}\right.$ DHA), $\delta 6.2-8.0(4 \mathrm{H}, \mathrm{m}, \mathrm{Ar}-\mathrm{H}), \delta 15.8(1 \mathrm{H}, \mathrm{s}, \mathrm{OH})$

Mass $(\mathrm{m} / \mathrm{z}):(\mathrm{M}+) 380(\mathrm{M}+1) 382$

\section{BIOLOGICAL ACTIVITY}

\section{Preparation of media plates for maintenance of bacteria} and fungus

Nutrient agar $(28 \mathrm{gm} / 1000 \mathrm{ml})$ was dissolved in 1 lit conical flasks and sterilized in autoclave at $121^{\circ} \mathrm{C}(15 \mathrm{lbs} /$ sq. inches) for 20 minutes. Potato dextrose agar (39 gm/lit) was dissolved in 1 lit conical flasks and sterilized in autoclave at $121^{\circ} \mathrm{C}(15 \mathrm{lbs} / \mathrm{sq}$. inches $)$ for 20 minutes. After cooling medium was poured in sterilized petri plate about $25 \mathrm{ml}$. The media plates were inoculated aseptically with inoculums. The bacterial culture of $S$. aureus, E. coli, Salmonella typhi were inoculated on nutrient agar medium. The bacterial culture plates were incubated for $24 \mathrm{hrs}$ in Biological oxygen demand (BOD) incubator at $28^{\circ} \mathrm{C}$ temperature growth of organism. The fungus culture plates were inoculated on potato dextrose agar medium. The fungal culture of Fusarium oxysporum, Candida albilans and Aspergillus flavas plates were incubated at $35-37^{\circ} \mathrm{C}$ temperature in BOD incubator growth of organism ${ }^{14-16}$.

Antimicrobial activity of compounds by agar well diffusion method 
Prepared media plate which was not inoculated with pathogen was taken and the wells were bored into agar using a sterile $6 \mathrm{~mm}$ diameter cork borer, six bore was made in each plate. The culture of the test organism was spread on petri plate with sterilized spreader chalcone derivatives of desired concentration. The test compound $(250 \mu \mathrm{g} / \mathrm{mL})$ was dissolved in dimethyl sulphoxide and loaded on a sterile filter paper disc of $6 \mathrm{~mm}$ diameter. The petriplates containing nutrient agar medium were spread with $100 \mu \mathrm{L}$ of actively growing both culture of the test bacteria using sterile cotton swab and allowed to dry for 10 min. For fungal species, $100 \mu \mathrm{L}$ of active culture was spreaded on PDA. Then the impregnated discs were placed on the surface of inoculated agar medium. With respect to control DMSO is used as a control for testing antimicrobial activity ${ }^{17-18}$. The positive control was taken as chloramphenicol. The plates were allowed to incubate at room temperature for about $2 \mathrm{hr}$ and then plate were transferred to incubator at $28^{\circ} \mathrm{C}$ for bacterial culture and $35-37^{\circ} \mathrm{C}$ for fungal culture. After 3-4 days zone of inhibitions were examined and recorded. The experiments were performed in replication and average diameters of the zones of inhibition were calculated and mentioned in table 2.

The observation shows that both the substituted chalcone derivatives are positively having antimicrobial property in action. It seems to be bacterial and fungicidal activity in them. So, they can be used against different animal and plant pathogens to cure a disease as a protection agent $^{19-20}$.

Table 2 Antimicrobial activity of isoxazoline derivatives (MBO-I - MBO-V)

\begin{tabular}{|l|l|l|l|l|l|l|}
\hline \multirow{2}{*}{ Compound } & \multicolumn{2}{l}{$\begin{array}{l}\text { Bacteria } \\
\text { (Zone of Inhibition in mm) }\end{array}$} & \multicolumn{3}{l|}{$\begin{array}{l}\text { Fungi } \\
\text { (Zone of Inhibition in mm) }\end{array}$} \\
\hline & A & B & C & D & E & F \\
\hline MBO-I & 23 & 22 & 22 & 20 & 19 & 18 \\
\hline MBO-II & 19 & 18 & 23 & 18 & 17 & 17 \\
\hline MBO-III & 16 & 17 & 21 & 15 & 14 & 15 \\
\hline MBO-IV & 20 & 21 & 23 & 19 & 18 & 16 \\
\hline MBO-V & 16 & 15 & 19 & 13 & 14 & 14 \\
\hline $\begin{array}{l}\text { Chloramphenicol } \\
(250 \mu \text { g/ml) }\end{array}$ & 24 & 25 & 22 & 20 & 22 & 22 \\
\hline DMSO & -ve & -ve & -ve & -ve & -ve & -ve \\
\hline
\end{tabular}

*Standard, A-Staphylococcus aureus, B-Escherichia coli , C- Salmonella Typhi , D-Fusarium oxysporum, E- Candida albicans, F-Aspergillus flavus.

\section{RESULT AND DISCUSSION}

A series of novel substituted isoxazoline were synthesized by refluxing a mixture of DHA chalcone (MBC-I-MBC-V), hydroxylamine hydrochloride and sodium acetate in the presence of ethanol,the reaction is completed within 6-7 $\mathrm{hr}$ as monitored by TLC providing good to excellent yield 75-80\% (MBO-I-MBO-V).

All the synthesized substituted isoxazoline derivatives were confirmed on the basis of Spectral analytical data (IR, ${ }^{1} \mathrm{H}$ NMR, Mass and Elemental analysis)

The IR spectra of the isoxazoline derivatives showed disappearance of $\mathrm{C}=\mathrm{O}$ bond of chalcone, a strong band appears at $1590-1615 \mathrm{~cm}^{-1}$ assigned to $\mathrm{C}=\mathrm{N}$ because of ring closure. The absorption band $1450-1465 \mathrm{~cm}^{-1}$ due to $\mathrm{CH}_{2}$ of isoxazoline ring present in the respective compounds.

${ }^{1} \mathrm{H} \quad \mathrm{NMR}$ Spectra of some representative compound were recorded which show the characteristic peaks at $83.0-3.6\left(\mathrm{dd}, 2 \mathrm{H}, \mathrm{CH}_{2}\right.$ i.e. $\mathrm{H}_{\mathrm{A}}$ and $\mathrm{H}_{\mathrm{B}}$ of isoxazoline ring), $\delta 5.2-5.4\left(\mathrm{t}, 1 \mathrm{H}, \mathrm{CH}\right.$ i.e. $\mathrm{H}_{\mathrm{X}}$ of isoxazoline ring) were observed, all the other aromatic and aliphatic proton were observed at the expected region.

The antimicrobial activities were tested against the bacterial and fungal species as mentioned in methodology, the effective zone of inhibition were observed at each concentrations mentioned in Table 2. All the isoxazoline compounds are having effective antimicrobial properties as shown in Fig 2. The results were compared with standard chloromphenicol and the positive control was taken as DMSO. There was no zone of inhibition in DMSO on microbial growth. Both the organism's i.e. bacteria and fungi showed maximum zone of inhibition i.e. $23 \mathrm{~mm}$ and $21 \mathrm{~mm}$, respectively as shown in Table 2.

In conclusion, the synthesized isoxazoline compound possesses a good to moderate biological properties. These compounds will be having application in pharmaceutical, agriculture, medical field for drug development.

\section{REFERENCES}

[1] Haripara K, Patel S, Joshi A and Paresh H, Indian J Heterocycl Chem., 2004; 13:221.

[2] Wagner E, Becam L and Nowakowska E, Bioorg Med Chem., 2004; 12: 265-272.

[3] Ngaini Z, Siti M Haris-Fadzillah, Hasnain Hussain and Kamarulzamon Kamoruddin,

[4] World J Chem., 2009; 4(1): 09-14.

[5] Vogel A I, Textbook of Practical Organic Chemistry, $4^{\text {th }}$ Ed., Longman, 1981;1371p.

[6] Collin C H, Microbiological Methods, Butter Wrths, London, 1964; 92.

[7] Gravestock M B and Ryley J F, Annual Reports in Medicinal Chem., 1984; 19: 127-136.

[8] Dunstan WR and Dymond TS. J Chem Soc., 1891; 59: 410-433.

[9] Ajay Kumar K, Govindaraju M, Jayaroopa P and Vasanth Kumar G. Int J Pharma Chem Bio Sci.. 2013; 3(1): 91-101.

[10] Ajay Kumar K, Renuka N and Vasanth Kumar G. Int J Pharm Tech Res., 2013; 5(1): 239- 248

[11] Ajay Kumar K, Lokeshwari DM, Pavithra G and Vasanth Kumar G. Res J Pharm Tech., 2012; 5(12): 1490-1496.

[12] Jawalekar AM, Reubsaet E, Rutjes Floris PJT and van Delft FL Chem Commun., 2011; 47: 3198-3200.

[13] Sandeep B, Santosh K, Uppuleti VP, Venkata PP and Debnath B. Tetrahedron Lett., 2009; 50: 3948-3951.

[14] Shravankumar K, Ravinder V, Chandra Sekhar V. Org Biomol Chem. 2011: 9: 7869- 7876

[15] Nagatoshi N, Kazuya K, Shotaro H, Jun S, Kazuhiko S, Yumiko I, Maho N and Masahiro A. Org Biomol Chem., 2012; 10:1987-1991. 
[16] Bhaskar Chakraborty, Manjit Singh Chhetri, Saurav Kafley and Amalesh Samanta. Indian J Chemistry., 2010; 49B: 209-215.

[17] Stokes BJ, Vogel CV, Urnezis LK, Pan M and Driver TG. Org Lett., 2010; 12(12): 2884- 2887.

[18] Waldo JP and Larock RC. Org Lett., 2005; 7: 5203-5205.

[19] Ajay Kumar K, Lokanatha Rai KM and Umesha K. Journal Chem Res (S)., 2001; 436- 438.

[20] Hemant S Chandak. Der Pharma Chem., 2012; 4(3): 1054-1057.

[21] Ajay Kumar K, Lokanatha Rai KM, Umesha KB and Prasad KR. Ind J Chem., 2001; 40B: 269-273. 